Information Management and Business Review

Vol. 5, No. 10, pp. 499-504, Oct 2013 (ISSN 2220-3796)

\title{
Participant Observation in a Case Study on Web Design Process of E-retail Website
}

\author{
*Rashdan Bin Rashid, Shahizan Hassan \\ Othman Yeop Abdullah Graduate School, Universiti Utara Malaysia, Malaysia \\ *pkksabah@yahoo.com
}

\begin{abstract}
Studies on developing models for e-retail implementation for consumer co-operative business are very scarce. Co-operative businesses appear to be anxious about going into online retailing since Malaysian Internet shopping is still new, customers are not very familiar and skeptical towards online shopping. Consequently a case study (participant observation) will be undertaken in this study to accomplish main aim in implementation Content Management System (CMS) in developing design process of consumer co-operative website. Web design process model by Kiatruangkrai et al. (2010) and Goi(2007a) have been the foundation guideline in designing the website. Package selection web based application has been used in design stage which can easily help non professional web developer to design their online shopping website. As a conceptual paper, this research is limited to literature and prior research. It offers the benefit to new direction for further research on web design process model. This paper provides researcher with a proposed model of web design process. The proposed model should also be tested in relation with e retail business.
\end{abstract}

Keywords: Content Management System (CMS), participant observation, e-retail, design process, co-operative business

\section{Introduction}

Changes in the economy, politics, environment, market liberalization, emergence of new technologies and development of Information and Computer Technology (ICT) demand the co-operatives to be more innovative in doing business to enhance their competitiveness and resilience (Dasar Koperasi Negara 20112020, 2010). Initiatives such as Small Retailer Transformation Programme (TUKAR) and Get Malaysian Business Online (GMBO) were introduced by the government due to the potential of the Internet to enhance business and allow enterprise to operate e-commerce at a low cost. Indeed, the Internet has become the means for firms and consumers to conduct businesses. The impact of World Wide Web (WWW) has been so huge in retail sector which has resulted into a new form of retail format known as electronic retailing or etailing (Zetty Madina et al., 2011). Despite the government's initiatives and programmes to spearhead the utilisation of the internet for business, little is known about how traditional business can provide competitive advantage and make it appealing to customer in the e-retail business market (Delafrooz, Laily \& Khatibi, 2010; Haque, Sadeghzadeh \& Khatibi, 2006). Empirical evidence indicates that there are several reasons as to why there are less attention and interest given to e-retail. Ultimately, cost is the major reason found to be linked with the less participation of doing online business (Burke, 2002; Haque et al., 2006; Kauffman \& Walden, 2001; Norzieiriani, Azizah \& Ramayah, 2010; Paynter \& Lim, 2001). Nonetheless, most of the studies on online shopping web design or site building seemed to rely on a single methodology, which is quantitative methodology and many are related to identifying web design variables. Whereas e-retailers should have some form of methodology/standard/best practise guide for web design project (Taylor, McWilliam, Forsyth \& Wade, 2002). Extensive review on previous research on web design. there are lack of research that used case study methodology. Web developer introduces web Content Management System (CMS) in helping web designers to solve issues in web design process which the non-professional can easily and quickly develop website in the practical application (Zhao \& Du, 2010). CMS in web design package selection is a tool that can make the website design less complicated (Nurminen, Wikman, Kokkinen, Muilu \& Grönholm, 2008; Zhao \& $\mathrm{Du}, 2010)$. This conceptual research paper differs as it is designed to stress on the incorporation of CMS in web design process model because a proper participant observation in a case study web design process using CMS package selection in e-commerce is still rarely studied and should be revised to accommodate the need of non-professional developers. 


\section{Literature Review}

According to Goi (2007) a good quality website is not solely based on the perception of the web developer but also based on the customers' acceptance and perception towards it. The website design should be simple and should not confuse potential customers who might not be familiar with online shopping (Khatibi, Haque \& Khaizurah, 2006). The model of website design must has credibility for consumer to be rely on (Bailey, 2005). Thus, it is essential that online shopping through websites is designed to make it easy, simple and convenient (Haque et al., 2006). Such as research by Hausman and Siekpe (2009) which indicate that tool bars (e.g. button, dropdown menu, check box, etc.) and web design features (e.g. background colour, visual images, information density, etc.) have had an impact on useful, informative and entertainment. Previous researchers (academia) study on various factors in website design such as, information needed, business responses and email, security of consumers' transaction, payment and credit policies, shipping and handling costs; and guarantees about product quality in an empirical study using single methodology to get customers' acceptance (Delafrooz et al., 2010; Sharma et al., 2007; Teo, 2006; Wu, 2003). Those researchers are focusing on finding the relationship between variables as the posibility of making website an effectiveness. While in web design research among IT researchers are mostly on the architacture of CMS in various context such as portal, library, education and e commerce (Benzing, 2006; Cheek, Shehab, Ung \& Williams, 2011; Islam, 2011; Nurminen et al., 2008) in web design.

Table 1: Summary of previous research on web design

\begin{tabular}{|c|c|c|c|}
\hline Researcher & Focus & Method & Types of website \\
\hline $\begin{array}{l}\text { Siddiqui, O’Malley, } \\
\text { McColl and Birtwistle } \\
(2003)\end{array}$ & $\begin{array}{l}\text { Retail Information, Customer } \\
\text { Information, Site Features, } \\
\text { Online shopping capabilities, } \\
\text { Online Payment Method, } \\
\text { Distribution Capacity and } \\
\text { fulfillment } \\
\text { expectations }\end{array}$ & $\begin{array}{l}\text { Exploratory } \\
\text { Qualitative } \\
\text { Method }\end{array}$ & Online fashion website \\
\hline Bailey (2005) & $\begin{array}{l}\text { Consumer awareness, } \\
\text { Use }\end{array}$ & Questionnaire & Product review website \\
\hline $\begin{array}{l}\text { Hausman and Siekp } \\
\text { (2009) }\end{array}$ & $\begin{array}{l}\text { Web interface: } \\
\text { Usefulness } \\
\text { Informativeness } \\
\text { Entertainment } \\
\text { Irritation }\end{array}$ & $\begin{array}{l}\text { Lab experiment } \\
\text { and Questionnaire }\end{array}$ & $\begin{array}{l}\text { Dell.com and } \\
\text { Landsend.com website }\end{array}$ \\
\hline Seman et al. (2009) & $\begin{array}{l}\text { Attractiveness, Visual Style, } \\
\text { Motivation }\end{array}$ & $\begin{array}{l}\text { Experimental and } \\
\text { Interview, } \\
\text { Questionnaire }\end{array}$ & $\begin{array}{l}\text { Telecommunication } \\
\text { website in Malaysia }\end{array}$ \\
\hline Bamasoud (2010) & User Interface & Usability Testing & e-commerce website \\
\hline $\begin{array}{l}\text { Noorfadzilah et al. } \\
(2010)\end{array}$ & Web development & Case study & Shopping2u.com \\
\hline Liu et al. (2010) & $\begin{array}{l}\text { Web design } \\
\text { Implementation }\end{array}$ & Case study & $\begin{array}{l}\text { Customized } \\
\text { website }\end{array}$ \\
\hline H. Im and На (2011) & $\begin{array}{l}\text { Enjoyment, } \\
\text { Involvement, }\end{array}$ & $\begin{array}{l}\text { Online experiment } \\
\text { survey }\end{array}$ & Two mock website \\
\hline
\end{tabular}

Researcher suggested businesses to innovate a form of method for web development project (Taylor et al., 2002). In order to benefit from this innovative technology, co-operatives should be able to adapt with this new paradigm shift of doing business. However, the opposite is found in the co-operatives business environment in Malaysia. Co-operative businesses appear to be anxious about going into online and have been proven by limited website among the retail co-operatives establishment found in Malaysia. Previous research by Yousept and Li (2005), used case study of ASDA.com to describe the challenges in building and 
developing an online grocery business in UK. The research illustrates the development stage and critical aspects of ASDA.com's web store. The illustrations were more on managerial aspects experience but not on technical aspects on the development of the web store.

An example of process model in web design studies in general can be seen on a few models and terms. Other terms in showing the web design process commonly used by IS researcher are web engineering and software engineering. Four basic principles of web engineering can be described similarly to system engineering: clearly defined goals, systematic development of a web application in phases, careful planning of the phases and continuous audit (Kappel, Proll, Reich \& Retschitzegger, 2003). However, web engineering approach may lead to complex applications that are difficult for non-professional web designer to use and to maintain (Cunliffe, 2000). Those life cycle models are suitable for professional web designer and using complex applications. Some organisations tend to implement a package selection in order to overcome complex application. Weaver (2004) explained that some systems are being implemented using a package selection especially in standard applications such as accounting and in a small business where resources are limited. There were two process model that suitable to be adapted for this research because directly in the context of e-commerce. According to Zhao and $\mathrm{Du}$ (2010), Web site Content Management System is a website application platform for web design. It enables user to quickly develop, maintain, manage the dynamic website and lend structure and manage contents online (Islam, 2011). Kiatruangkrai et al. (2010) proposed a method specifically in CMS and e-commerce environment to design and develop a website. This research has identified four stages for the development process. Table 1 described the summary of stages in CMS for ecommerce.

\section{Table 2: Summary of CMS stages for e commerce}

\begin{tabular}{ll}
\hline Stages & Description \\
\hline Requirement Gathering & Survey and Observation. Asked employers and interviews firms that used \\
& CMS. \\
Design & Involved System Architecture, System Functions, User Interface, System \\
& Security and database \\
Implementation & Develop using HTML, CSS and PHP Language \\
Testing & Unit testing, Integration testing and System Testing \\
\hline
\end{tabular}

Source: (Kiatruangkrai et al., 2010)

Goi (2007a) reviewed the relevant web site development models. The research mentioned that in a website design, the purpose of particular web site was developing either for information design, transactional design or both. The study categorised website development into four stages: The initial part of the study discussed the Planning and Preparation Stage which was to gather information about personnel and skills, facilities and equipment, software, financial investment and time commitment. Subsequently, the Development and Design Stage which focused on the tangible content and design was evaluated in the study. Followed by, the Management and Maintenance Strategy were monitoring and reviewing website pages. Lastly, the Internet Marketing which was involved in managing the function of communication, transaction and distribution. The study specifically reviewed the relevant web site development models on e-commerce website but not practically be tested in end user business environment. According to Kappel et al. (2003), given an appropriate web design process model, inexperienced web designer may be able to reduce the complexity of the applications, improve usability, maintainability and can also achieve user acceptance. Web design process model by Kiatruangkrai et al. (2010) and Goi(2007a) involved in e-commerce environment and the stages are suitable to be adapted for this research.

\section{Methodology}

The research seeks explanation through participant observation case study on the process of web design on co-operative e-retail website. It is a bottom-up approach where from the case study research, researcher will build the process model (Eisenhardt, 1989). An outcome will be a co-operative e-retail website. Case Study method will be employed to develop process model of e-retail website for co-operative. For the purpose of website design, this study will uses a software tools called Content Management System (CMS) package selection application to design the website. Single case study will be used as Tuanku Syed Sirajuddin Polytechnic Co-operative Limited will be the case. According toTaylor, McWilliam, Forsyth and Wade (2002) 
case study is appropriate for investigating current IT practice because it can help researcher to overcome the problem of terminology and verification compared to other research methods. However, it is a time consuming nature of study and difficult to gain access to the organisations. Iacono, Brown and Holtham (2009) stated that case study is suitable to the information systems in organization because management can focus on organization rather than on technical issues. Furthermore, IS researchers are often unable to provide guidance on how to manage the introduction of new systems due to continuous revolutionary change and lag behind practitioners. Hence, participant observation which has been associated with qualitative methods offer the chance to obtain unique insights into the organization or social group and fully accepted for IS research (Iacono et al., 2009). Researcher acts as a participant-observation. According to Yin (2009) participant-observation is a special mode of observation whereby researcher actually participates in the events being studied. In the case study, the issue is to what extend can the findings be extrapolated to the theory that the researcher designed to test (Brannen, 1992). This gives shoppers a more realistic sense of how the applications operate and the benefits they provide, allowing accurate assessment of value (Burke, 2002). Participant observation demands first hand invovement in the study because researcher is as an instrument, researcher hears, sees, and begins to experience reality as the participants do, and researcher's presence in the lives of the participants (Marshall \& Rossman, 2009). Even according to Jorgensen (1989), the methodology of participant observation is exceptional for studying processes, but participant observation is especially appropriate for scholarly problems when there are important differences between the views of insiders as opposed to outsiders, the phenomenon is somehow obscured from the view of outsiders and the phenomenon is hidden from public view. In short, then, the methodology of participant observation provides direct experiential and observational access to the insiders' world of meaning the world of everyday life.

The major criticsm on participant observation is the potential lack of objectivity because the researcher is not an independent observer but a participant whereas the phenomenon being observed is the subject of research (Iacono et al., 2009). A field test can also provide detailed information on the costs of installing and maintaining technology, highlight issues of employee acceptance and training, and provide feedback on competitive response. This research follow Iacono et al. (2009) in managing participant observation whereby they have include subjective experience and their own experience. In order for researcher to understand, develop and manage the actual process in web design, participant observation is appropriate for this research. Figure 1 shows the activities and tasks during the participant observation technique.

\section{Figure 1: The main stages in the proposed web design process model methodology}

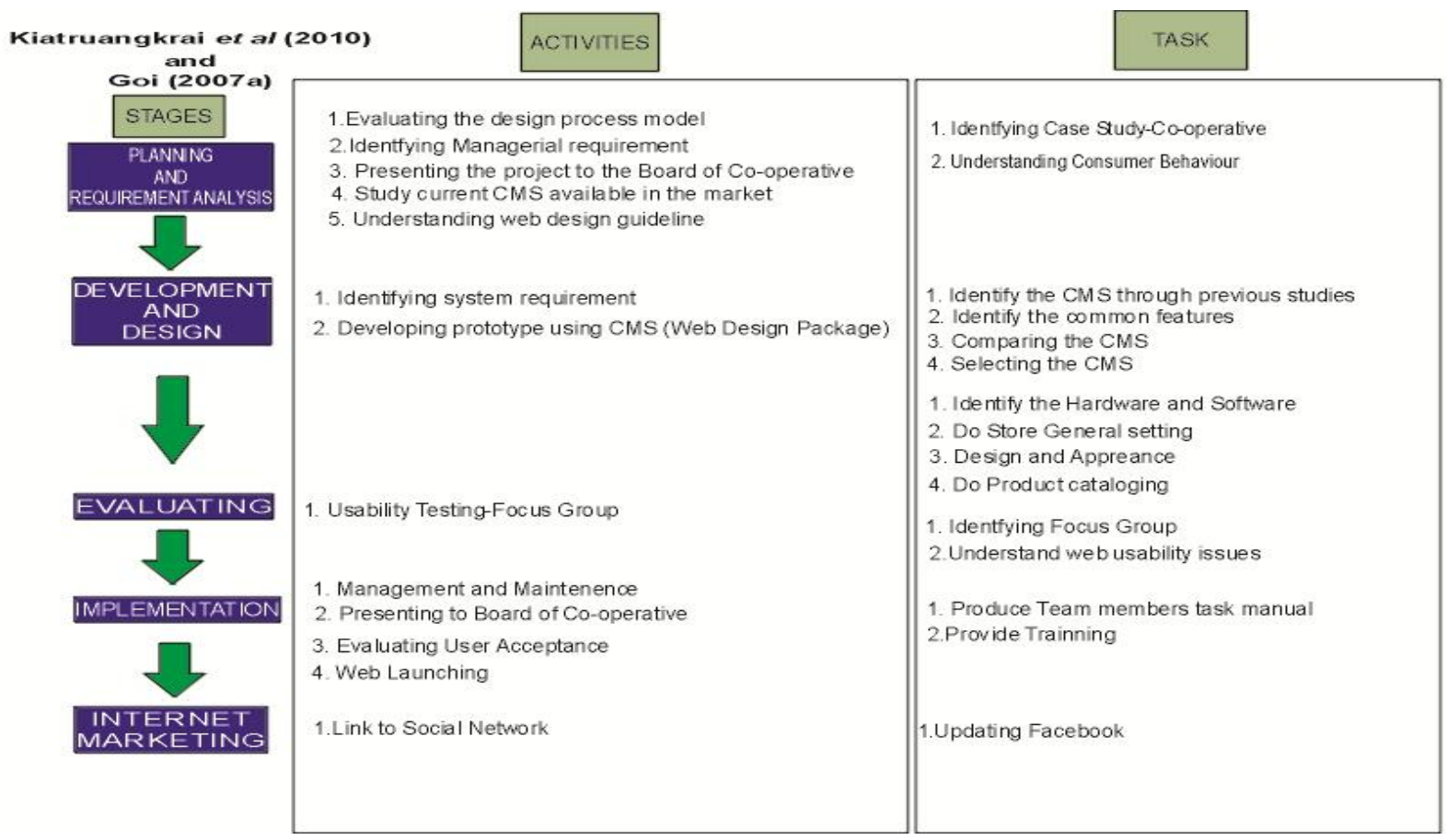


Planning and Requirement will be on the review of literature especially on process model and the identifying management requirement. Presenting to Board of co-operative is to get managerial approval from the board of co-operative. The researcher will review the literature on the relevancies of stages in web design, web development and web engineering. In addition, this research will also review on the justification for cooperative to venture in online shopping business such as on identifying target market and products identification. In the development and design stage, researcher conducts case study through participant observation technique. The particular website is developed by using CMS package approach. There are many webhosting service providers that provide online shopping platforms in Malaysia such as www.netbuilder.com.my, webserver.com.my, lelong.my, exabytes.com.my, webshaper.com.my and others. There are many e-commerce CMS web application pre-loaded at webhosting services such as Zen Cart, Magento, Freeway, osCommerce, phpShop etc. Comparison will be conducted among the selected web hosting providers based on the requirements. In the evaluation stage, usability testing is conducted, purposive sampling is used which only includes students at Tuanku Syed Sirajuddin Polytechnic due to time limitation. Focus group will be conducted with the minimum sample size of 3-5 participants (Creswell \& Miller, 2000). Implementation stage is the launching of the website. The distribution of task among team members in order to manage products and orders will be documented in documents. Team members also undergo training on related tasks. Since that Goi, (2007b) insert Internet Marketing in the stages, this research will show the integration of Facebook to the product list. Statistical report on sales, Facebook and Google analytical will be reported. Both researcher will be adapted as a process model due to certain condition. The process model was related directly with the usage of CMS and in e commerce environment. In order to enhance the process, this research will also further the study by testing the process model in an e-retail environment.

\section{Discussion and Conclusion}

There are significant gaps between academia and practitioner in implementation of e retail business. Academia publications are appear to concentrate on identifying web design variables (empirical single methodology) whereas practitioners are more on web designing process model (case study). This research developed a process model to explain various stages of developing e-retail website in co-operative business. It explains activities and tasks need as an ideal framework for such purposes on doing e retail business. To illustrate the use of the processes model, researcher will participate in the process on co-operative e-retail business.

\section{References}

Bailey, A. A. (2005). Consumer awareness and use of product review websites. Journal of Interactive Advertising, 6(1), 68-81.

Benzing, M. (2006). Luwak: a content management solution. Library Hi Tech, 24(1), 8-13. doi:10.1108/07378830610652077

Brannen, J. (1992). Combining qualitative and quantitative approavhes: an overview. Mixing Methods: Qualitative and Quantitative Research (pp. 1-37). Avebury.

Burke, R. (2002). Technology and the customer interface: What consumers want in the physical and vitual store. Journal of the Academy of Marketing Science, 30(4), 411-432.

Cheek, G., Shehab, M., Ung, T. \& Williams, E. (2011). iLayer: Toward an Application Access Control Framework for Content Management Systems. 2011 IEEE International Symposium on Policies for Distributed Systems and Networks, 65-72. doi:10.1109/POLICY.2011.28

Creswell, J. W. \& Miller, D. L. (2000). Determining validity in qualitative inquiry. Theory into Practice, 39(3), $124-131$.

Cunliffe, D. (2000). Developing usable web sites - a review and model. Internet Research: Electronic Networking Applications and Policy, 10(4), 295-307.

Dasar Koperasi Negara 2011-2020. (2010). (1st ed., pp. 1-39). Suruhanjaya Koperasi Malaysia.

Delafrooz, N., Laily, H. P. \& Khatibi, A. (2010). Students' online shopping behavior : An empirical study. Journal of American Science, 6(1), 137-147.

Eisenhardt, M. (1989). Building theories from case study research. The Academy og Management Review, $14(4), 532-550$. 
Goi, C. L. (2007a). A review of existing web site models for e-commerce. Journal of Internet Banking and Commerce, 12(1), 1-17.

Goi, C. L. (2007b). Correlation between Internet and ICT, Web Site Development, and Internet Marketing: Perception of Marketers in Malaysia and Singapore. Journal of Internet Banking and Commerce, 12(2).

Haque, A., Sadeghzadeh, J. \& Khatibi, A. (2006). Identifying potentiality online sales in Malaysia: A study on customer relationships online shopping. Journal of Applied Business Research, 22(4), 119-130.

Hausman, A. V. \& Siekpe, J. S. (2009). The effect of web interface features on consumer online purchase intentions. Journal of Business Research, 62(1), 5-13. doi:10.1016/j.jbusres.2008.01.018

Iacono, J., Brown, A. \& Holtham, C. (2009). Research methods - A case example of participant observation. The Electronic Journal of Business Research Methods, 7(1), 39-46.

Islam, N. (2011). Understanding continued usage intention in e-learning context. 24th Bled eConference efuture:Creating Solutions for the Individual, Organisations and Society (pp. 546-557). Bled, Slovenia.

Jorgensen, D. L. (1989). Participant Observation. In D. L. Jorgensen (Ed.), Participant Observation (pp. 12-26). Thousand Oaks: SAGE Publications.

Kappel, G., Proll, B., Reich, S. \& Retschitzegger, W. (2003). Web Engineering: The Discipline of Systemativ Development of Web Applications. Heidelberg: John Wiley \& Sons Limited.

Kauffman, R. J. \& Walden, E. A. (2001). Economics and electronic commerce: Survey and directions for research. International Journal of Electronic Commerce, 5(4), 5-116.

Khatibi, A., Haque, A. \& Khaizurah, K. (2006). E-commerce: A study on internet shopping in Malaysia. Journal of Applied Sciences, 6(3), 696-705.

Kiatruangkrai, P., Phusayangkul, P., Viniyakul, S., Prompoon, N. \& Kanongchaiyos, P. (2010). Design and Development of Real-Time Communication Content Management System for E-Commerce. 2010 Second International Symposium on Data, Privacy, and E-Commerce (pp. 111-116). Ieee. doi:10.1109/ISDPE.2010.24

Marshall, C. \& Rossman, G. . (2009). Designing Qualitative Research (4th ed.). SAGE Publications.

Norzieiriani, A., Azizah, O. \& Ramayah, T. (2010). Consumer lifestyles and online shopping continuance intention. Business Strategy Series, 11(4), 227-243. doi:10.1108/17515631011063767

Nurminen, J. K., Wikman, J., Kokkinen, H., Muilu, P. \& Grönholm, M. (2008). Drupal content management system on mobile phone personal mobile website Apache Symbian MySQL. IEEE Computer Society (pp. 1228-1229).

Paynter, J. \& Lim, J. (2001). Drivers and impediments to e-commerce in Malaysia. Malaysian Journal of Library \& Information Science, 6(2), 1-19.

Sharma, A., Singhal, Y. K., Makhija, D., Goyal, A. K., Agarwal, N. \& Bakhshi, A. (2007). Factors affecting e-tailing website effectiveness: An Indian perspective. Second International Conference on Internet and Web Applications and Services (ICIW'07) (pp. 41-41). Ieee. doi:10.1109/ICIW.2007.33

Taylor, M. ., McWilliam, J., Forsyth, H. \& Wade, S. (2002). Methodologies and website development: a survey of practice. Information and Software Technology, 44(6), 381-391. doi:10.1016/S0950-5849(02)000241

Teo, T. S. H. (2006). To buy or not to buy online: adopters and non-adopters of online shopping in Singapore. Behaviour \& Information Technology, 25(6), 497-509. doi:10.1080/01449290500256155

Weaver, P. (2004). Success in Your Project A Guide to student System Development Project. Prentice Hall Financial Times.

$\mathrm{Wu}$, S. I. (2003). The relationship between consumer characteristics and attitude toward online shopping. Marketing Intelligence \& Planning, 21(1), 37-44. doi:10.1108/02634500310458135

Yin, R. K. (2009). Case Study Research Design and Methods (4th ed.). SAGE Publications.

Yousept, I. \& Li, F. (2005). Building an online grocery business : The case of asda.com. International Journal of Cases on Electronic Commerce, 1, 57-78.

Zetty Madina, M. Z., Norazlin, R., Fatimah, A. G., Azlina, S., Munirah, H., Jusoff, K. \& Norzaidah, N. (2011). Online grocery shopping: The affect of time availability on Malaysian consumer preferences. World Applied Sciences Journal, 12, 60-67. Retrieved from http://www.idosi.org/wasj/wasj12(SSTE)/10.pdf

Zhao, L. \& Du, S. F. (2010). Design and implementation of j2EE-based web website content management system. 2010 International Conference on E-Product E-Service and E-Entertainment (pp. 1-4). IEEE International. doi:10.1109/ICEEE.2010.5660870 